\title{
Pengaruh Penambahan Bubuk Jahe Emprit (Zingiber officinale var. Amarum) Terhadap Karakteristik Teh Celup Herbal Daun Salam (Syzygium polyanthum (Wight.) Walp)
}

\section{Effect of Emprit Ginger (Zingiber officinale var. Amarum) Powder Additions on the Characteristic of Bay Leaf Herbal Tea Bag (Syzygium polyanthum (Wight.) Walp)}

\author{
Ida Ayu Putu Jasmine Chandra Dewi ${ }^{1}$, I Putu Timur Ina ${ }^{1 *}$, Ni Luh Ari Yusasrini ${ }^{1}$ \\ Program Studi Teknologi Pangan, Fakultas Teknologi Pertanian, Universitas Udayana \\ Kampus Bukit Jimbaran, Badung-Bali \\ *Penulis korespondensi: Putu Timur Ina, Email: timurina@unud.ac.id
}

\begin{abstract}
This research was aimed to determine the effect of the emprit ginger powder additions on the characteristics of bay leaf herbal tea bag and to determine the appropriate addition of emprit ginger powder to get the best bay leaf herbal tea bag characteristics. The design used in this study was a Completely Randomized Design (CRD) with an additional emprit ginger powder treatment with consisting of 5 namely: $0 \%, 5 \%, 10 \%, 15 \%$, and $20 \%$. This study was repeated 3 times so that they were obtained 15 experimental units. The data obtained were analyzed by analysis of variance (ANOVA) and if the treatment had a significant effect followed by Duncan's Multiple Range Test (DMRT). The results showed that the addition of $20 \%$ emprit ginger powder had a significant effect $(\mathrm{P}<0,05)$ on moisture content, extract content in water, phenol total, flavonoid total, antioxidant activity, $\mathrm{IC}_{50}$, hedonic test and scoring test (aroma and taste). The results showed that bay leaf herbal tea bag with the addition of $20 \%$ emprit ginger powder was the best treatment with moisture content $8.93 \%$, extract content in water $16.97 \%$, phenol total $3.35 \mathrm{mgGAE} / \mathrm{g}$, flavonoid total $0.62 \mathrm{mgQE} / \mathrm{g}$, antioxidant activity $73.90 \%, \mathrm{IC}_{50}$ value $640.99 \mathrm{ppm}$. The characteristics of the brewed tea water such as the color was common, the typhical aroma of emprit ginger and liked, the typhical taste of emprit ginger and liked, and overall acceptance was liked.
\end{abstract}

Keywords: bay leaf, emprit ginger, tea bags

\section{PENDAHULUAN}

Teh herbal merupakan salah satu jenis minuman yang bukan berasal dari daun teh (Camellia sinensis), tetapi berasal dari bunga, daun, akar, biji, atau tanaman kering (Ravikumar, 2014). Teh herbal berkhasiat bagi tubuh seperti mencegah/mengurangi penyakit jantung dan kanker (Suharmiati, 2003), memperbaiki pencernaan, dan memperlambat proses penuaan (Tjay dan Rahardjo, 2007). Di Indonesia, masyarakat cenderung memilih produk yang lebih praktis, tidak terkecuali dalam proses penyeduhan teh. Hal ini disebabkan karena gaya hidup masyarakat yang semakin menginginkan kepraktisan (Imanila et al., 2018). Oleh karena itu, produsen teh melihat peluang tersebut untuk menciptakan produk teh yang mudah diseduh yaitu dengan teh celup. Penggunaan teh celup disebabkan karena teh celup tidak perlu menggunakan proses penyaringan sehingga memudahkan masyarakat untuk mengonsumsi teh (Dewi et al., 2016). Hal ini membuat hasil olahan teh herbal dapat dijadikan sebagai teh celup. Teh celup dapat dibuat dari bahan baku selain dari daun teh, seperti daun rambusa (Nathaniel et al., 2020), daun kenikir (Aprilia et al., 2020), kulit kakao (Kusuma et al., 2019), dan daun salam (Dewi, 2018). Oleh karena itu, perlu dilakukan 
pengembangan mengenai penelitian yang telah dilakukan oleh Dewi (2018) tentang pembuatan teh celup dari daun salam.

Daun salam (Syzygium polyanthum (Wight.) Walp) merupakan salah satu jenis daun yang berbentuk lonjong sampai bundar dan berwarna hijau. Daun salam memiliki kandungan antioksidan yang tinggi. Hal ini dibuktikan pada penelitian Islamiyati dan Saputri (2008) bahwa ekstrak daun salam dengan etanol mempunyai nilai $\mathrm{IC}_{50}$ yaitu 7,59 ppm. Selain itu, daun salam mengandung senyawa flavonoid 14,87 mgQE/100 g (Mutiara et al., 2018), fenol $550 \mathrm{mgGAE} / 100 \mathrm{~g}$ (Ishtiaque $e t$ al., 2015) yang berguna bagi kesehatan tubuh seperti menurunkan kadar asam urat (Djohari dan Rovi, 2015), sebagai antidiare (Ambari, 2018), menurunkan kolesterol darah, trigliserida, dan tingkat LDL (Sutrisna, et al., 2018), serta menurunkan pembentukan plak gigi (Wiradona et al., 2015).

Penelitian daun salam telah dilakukan oleh Dewi (2018) mengenai pengaruh perbedaan suhu pengeringan terhadap karakteristik teh daun salam. Hasil penelitian Dewi (2018) menunjukkan bahwa pengeringan daun salam pada suhu $80^{\circ} \mathrm{C}$ menghasilkan teh daun salam dengan karakteristik terbaik dengan kriteria yaitu aktivitas antioksidan 91,04\%, total polifenol 28,23 mgGAE/g, kadar abu $4,06 \%$, dan kadar air 6,02\%. Penelitian tersebut memiliki kelemahan pada rasa teh herbal daun salam yaitu memiliki rasa sepat dan memiliki antioksidan yang rendah. Rasa sepat pada teh herbal daun salam disebabkan karena daun salam mengandung senyawa tanin sebesar $0,036 \%$ (Kharismawati et al., 2009). Oleh karena itu, perlu adanya penambahan bahan pangan lain yang dapat menutupi rasa sepat dan meningkatkan kandungan antioksidan pada teh herbal daun salam. Salah satu bahan yang dapat digunakan yaitu jahe emprit.

Jahe emprit (Zingiber officinale var. Amarum) merupakan bahan rempah yang biasanya digunakan pada industri obat, khususnya pada minuman jamu. Jahe emprit memiliki aroma dan rasa yang khas. Menurut Yuliani dan Suyanti (2012), aroma yang khas pada jahe emprit disebabkan karena jahe emprit mengandung minyak atsiri sebesar 3-3,3\%. Kandungan minyak atsiri yang terkandung di dalam jahe emprit yaitu zingiberene dan zingiberol. Selain itu, jahe emprit juga mengandung senyawa gingerol dan shogaol yang menyebabkan adanya rasa pedas pada jahe emprit. Menurut penelitian Fathona (2011), kandungan gingerol dan shogaol tertinggi terdapat pada jahe emprit sebesar 22,57 mg/g dan 2,24 mg/g dibandingkan dengan jahe merah sebesar 18,03 $\mathrm{mg} / \mathrm{g}$ dan $1,36 \mathrm{mg} / \mathrm{g}$ serta jahe gajah sebesar 9,56 $\mathrm{mg} / \mathrm{g}$ dan $0,92 \mathrm{mg} / \mathrm{g}$. Oleh karena itu diharapkan dengan penambahan jahe emprit mampu menambah rasa pada teh celup herbal daun salam.

Menurut penelitian Wisakarani et al., (2016) mengenai pengaruh penambahan bubuk jahe emprit terhadap karakteristik teh daun kelor menghasilkan karakteristik terbaik yaitu dengan penambahan bubuk jahe emprit sebesar $8 \%$ yang meliputi kadar air 5,53\%, kapasitas antioksidan 26,82 mg/100 g GAEAC, Vitamin C 5,42 mg/100 g asam askorbat, tingkat kesukaan terhadap aroma adalah agak suka, tingkat kesukaan terhadap rasa adalah suka, tingkat kesukaan terhadap warna dan penerimaan keseluruhan adalah suka. Berdasarkan 
hal diatas maka perlu dilakukan penelitian mengenai penambahan jahe emprit ke dalam teh celup herbal daun salam.

\section{METODE PENELITIAN}

\section{Tempat dan Waktu Penelitian}

Penelitian ini dilaksanakan di Laboratorium Nutrisi dan Makanan Ternak, Fakultas Peternakan, Universitas Udayana dan di Laboratorium Analisis Pangan serta Laboratorium Pengolahan Pangan, Fakultas Teknologi Pertanian, Universitas Udayana. Penelitian ini dilakukan pada bulan Juli September 2020.

\section{Bahan dan Alat}

Bahan yang digunakan dalam penelitian ini adalah daun salam yang dimulai dari daun termuda hingga empat helai daun yang diperoleh di Banjar Mambul, Desa Taman, Abiansemal, Bali dan jahe emprit diperoleh dari Pasar Cokroaminoto, Denpasar Barat, Bali. Bahan kimia yang digunakan yaitu 2,2-difenil-1-pikrilhidrazil (DPPH) (Himedia), reagen Folin-Ciocalteu (Merck), etanol pro analisis (PA), standar asam galat (Merck), $\mathrm{Na}_{2} \mathrm{CO}_{3}\left(\right.$ Merck), $\mathrm{AlCl}_{3}$ (Merck), standar kuersetin (Sigma) dan aquades.

Alat-alat yang digunakan pada penelitian ini yaitu oven kering (Memmert), timbangan analitik (Adam), blender (Cosmos), ayakan 40 mesh (Retsch), kantong teh berbahan kertas, sealer (PFS200), sentrifus (Clements 2000), spektrofotometer (Genesys 10S UV-Vis), vortex (Maxi Mix II Type 367000), desikator, mikro pipet (Eppendorf), tip mikro pipet, termometer, pisau, corong kaca (Pyrex), spatula, alumunium foil (Klin Pack), gelas ukur (Pyrex), botol gelap, gelas beaker, kufet kaca, pipet volume (Pyrex), pipet tetes, tabung reaksi (Pyrex), rak tabung reaksi, cawan porselin, tabung sentrifus, labu ukur $5 \mathrm{ml}$ (Pyrex), labu ukur $100 \mathrm{ml}$ (Pyrex), labu ukur $250 \mathrm{ml}$ (Pyrex), labu erlenmeyer (Pyrex), corong plastik, kertas saring, panci kukus, pinset, dan gelas plastik.

\section{Rancangan Penelitian}

Penelitian ini menggunakan Rancangan Acak Lengkap (RAL) dengan perlakuan penambahan bubuk jahe emprit terdiri dari 5 taraf sebagai berikut: $\mathrm{P} 0=$ bubuk jahe emprit $0 \%$; $\mathrm{P} 1=$ bubuk jahe emprit 5\%; P2 = bubuk jahe emprit 10\%; P3 = bubuk jahe emprit 15\%; P4 = bubuk jahe emprit $20 \%$. Masing-masing perlakuan diulang sebanyak 3 kali sehingga diperoleh 15 unit percobaan. Data yang diperoleh dianalisis menggunakan sidik ragam. Apabila perlakuan berpengaruh terhadap variabel yang diamati maka dilanjutkan dengan uji Duncan's Multiple Range Test (DMRT) menggunakan IBM SPSS Statistics 22 (Steel dan Torrie, 1993).

\section{Pelaksanaan Penelitian}

Tahap pelaksanaan penelitian meliputi tiga tahap yaitu pembuatan bubuk daun salam, pembuatan bubuk jahe emprit, dan pembuatan teh celup herbal daun salam.

\section{Pembuatan Bubuk Daun Salam}

Pembuatan bubuk daun salam menggunakan prinsip pengolahan teh hijau. Proses pemetikan daun salam dimulai dari daun termuda hingga empat helai daun dibawahnya dan disortasi dengan baik. Selanjutnya dilakukan proses pencucian dengan air mengalir dan ditiriskan. Daun salam dilayukan dengan cara steam (dikukus) pada suhu $100^{\circ} \mathrm{C}$ selama 1 menit. Daun salam yang sudah dikukus 
ditiriskan. Daun salam dikeringkan dalam oven pada suhu $60^{\circ} \mathrm{C}$ selama 3 jam. Daun salam kering dihaluskan dengan menggunakan blender dan diayak dengan ayakan 40 mesh dan didapatkan bubuk daun salam.

\section{Pembuatan Bubuk Jahe Emprit}

Pembuatan bubuk jahe emprit diawali dengan proses sortasi selanjutnya dicuci dengan air mengalir untuk menghilangkan kotoran. Jahe emprit dikupas sehingga terpisah dari kulit dan diiris tipis dengan ketebalan $3 \mathrm{~mm}$. Setelah diiris, jahe emprit diblansing dengan metode steam blanching (suhu $80^{\circ} \mathrm{C}$ selama 3 menit). Kemudian dikeringkan dalam oven pada suhu $60^{\circ} \mathrm{C}$ selama 6 jam. Jahe emprit kering selanjutnya dihaluskan dan diayak menggunakan ayakan 40 mesh sehingga didapatkan bubuk jahe emprit.

\section{Pembuatan Teh Celup Herbal Daun Salam}

Pembuatan teh celup herbal diawali dengan menimbang bubuk daun salam dan bubuk jahe emprit sesuai perlakuan, kemudian dilakukan pencampuran dan pengemasan menggunakan kantong teh berbahan kertas berukuran 5,2 x 5,8 cm dengan berat masing - masing kantong teh seberat 2 gram.

\section{HASIL DAN PEMBAHASAN}

\section{Hasil Analisis Bahan Baku dan Teh Celup Herbal Daun Salam}

Hasil analisis kadar, air, total fenol, total flavonoid, aktivitas antioksidan dan IC50 dari bubuk daun salam dan bubuk jahe emprit dapat dilihat pada Tabel 1. Hasil analisis kadar air, kadar ekstrak dalam air, total fenol dan total flavonoid teh herbal celup daun salam dapat dilihat pada Tabel 2 , sedangkan hasil analisis aktivitas antioksidan dan $\mathrm{IC}_{50}$ teh herbal celup daun salam dapat dilihat pada Tabel 3.

Tabel 1. Nilai rata-rata kadar air, total fenol, total flavonoid, aktivitas antioksidan, dan IC50 pada bubuk daun salam dan bubuk jahe emprit

\begin{tabular}{ccc}
\hline Komponen & Bubuk Daun Salam & Bubuk Jahe Emprit \\
\hline Kadar Air (\%) & 7,98 & 8,45 \\
Total Fenol (mgGAE/g) & 2,98 & 2,00 \\
Total Flavonoid (mgQE/g) & 0,45 & 0,20 \\
Aktivitas Antioksidan (\% inhibisi) & 32,75 & 60,21 \\
IC50 (ppm) & 1488,05 & 775 \\
\hline
\end{tabular}

\section{Kadar Air}

Hasil sidik ragam menunjukkan bahwa perlakuan penambahan bubuk jahe emprit berpengaruh nyata $(\mathrm{P}<0,05)$ terhadap kadar air teh celup herbal daun salam. Hasil penelitian menunjukkan nilai rata-rata kadar air teh celup herbal daun salam pada semua taraf perlakuan berkisar 7,95\%-8,92\% (Tabel 2). Kadar air semakin meningkat seiring dengan meningkatnya penambahan bubuk jahe emprit. Pada penelitian ini bubuk jahe emprit memiliki kadar air sebesar 8,45\%. Hal ini sesuai dengan penelitian Eze (2011) menyatakan bahwa bubuk jahe emprit memiliki kadar air berkisar antara $7-12 \%$. Kadar air dalam 
bahan pangan ikut serta dalam menentukan kesegaran, keawetan, dan mutu bahan pangan (Herawati dan Agus, 2007). Kadar air teh yang ditetapkan oleh SNI maksimal sebesar 10\%
(Anonimus, 2014). Hasil penelitian menunjukkan bahwa semua perilaku penambahan bubuk jahe emprit telah sesuai dengan standar mutu teh yang ditetapkan oleh SNI.

Tabel 2. Nilai rata-rata kadar air, kadar ekstrak dalam air, total fenol, dan total flavonoid teh celup herbal daun salam

\begin{tabular}{ccllc}
\hline $\begin{array}{c}\text { Perlakuan } \\
\text { penambahan } \\
\text { bubuk jahe } \\
\text { emprit }(\%)\end{array}$ & $\begin{array}{c}\text { Kadar Air } \\
(\% \mathrm{~b} / \mathrm{b})\end{array}$ & $\begin{array}{c}\text { Kadar Ekstrak } \\
\text { dalam Air }(\%)\end{array}$ & $\begin{array}{c}\text { Total Fenol } \\
(\mathrm{mgGAE} / \mathrm{g})\end{array}$ & $\begin{array}{c}\text { Total Flavonoid } \\
(\mathrm{mgQE} / \mathrm{g})\end{array}$ \\
\hline P0 $(0 \%)$ & $7,95 \pm 0,13 \mathrm{e}$ & $22,73 \pm 0,54 \mathrm{a}$ & $2,98 \pm 0,04 \mathrm{~d}$ & $0,45 \pm 0,020 \mathrm{e}$ \\
P1 (5\%) & $8,20 \pm 0,04 \mathrm{~d}$ & $20,73 \pm 1,49 \mathrm{ab}$ & $3,07 \pm 0,03 \mathrm{~cd}$ & $0,50 \pm 0,010 \mathrm{~d}$ \\
P2 (10\%) & $8,49 \pm 0,04 \mathrm{c}$ & $18,12 \pm 0,76 \mathrm{bc}$ & $3,16 \pm 0,08 \mathrm{bc}$ & $0,54 \pm 0,005 \mathrm{c}$ \\
P3 (15\%) & $8,73 \pm 0,06 \mathrm{~b}$ & $17,80 \pm 2,84 \mathrm{bc}$ & $3,23 \pm 0,05 \mathrm{~b}$ & $0,60 \pm 0,005 \mathrm{~b}$ \\
P4 (20\%) & $8,92 \pm 0,10 \mathrm{a}$ & $16,97 \pm 1,57 \mathrm{c}$ & $3,35 \pm 0,05 \mathrm{a}$ & $0,62 \pm 0,005 \mathrm{a}$ \\
\hline
\end{tabular}

Keterangan: Nilai rata-rata yang diikuti oleh huruf yang berbeda pada kolom yang sama menunjukkan perlakuan berbeda nyata $(\mathrm{P}<0,05)$

Tabel 3. Nilai rata-rata aktivitas antioksidan dan $\mathrm{IC}_{50}$ teh celup herbal daun salam

\begin{tabular}{ccc}
\hline $\begin{array}{c}\text { Perlakuan penambahan bubuk } \\
\text { jahe emprit (\%) }\end{array}$ & $\begin{array}{c}\text { Aktivitas Antioksidan } \\
\text { (\% inhibisi) }\end{array}$ & IC50 (ppm) \\
\hline P0 (0\%) & $32,75 \pm 0,52 \mathrm{e}$ & $1488,05 \pm 12,66 \mathrm{e}$ \\
P1 (5\%) & $43,40 \pm 0,56 \mathrm{~d}$ & $1140,53 \pm 18,00 \mathrm{~d}$ \\
P2 (10\%) & $55,60 \pm 0,33 \mathrm{c}$ & $920,22 \pm 12,73 \mathrm{c}$ \\
P3 (15\%) & $64,87 \pm 0,81 \mathrm{~b}$ & $735,43 \pm 24,55 \mathrm{~b}$ \\
P4 (20\%) & $73,90 \pm 0,06 \mathrm{a}$ & $640,99 \pm 19,75 \mathrm{a}$ \\
\hline
\end{tabular}

Keterangan: Nilai rata-rata yang diikuti oleh huruf yang berbeda pada kolom yang sama menunjukkan perlakuan berbeda nyata $(\mathrm{P}<0,05)$

\section{Kadar Ekstrak dalam Air}

Hasil sidik ragam menunjukkan bahwa perlakuan penambahan bubuk jahe emprit berpengaruh nyata $(\mathrm{P}<0,05)$ terhadap kadar ekstrak dalam air. Hasil penelitian menunjukkan nilai ratarata kadar ekstrak dalam air teh celup herbal daun salam berkisar 16,97\%-22,73\% (Tabel 2). Kadar ekstrak dalam air tertinggi diperoleh dari perlakuan P0 yaitu $22,73 \%$ dan tidak berbeda dengan P1. Kadar ekstrak dalam air terendah diperoleh dari perlakuan P4 yaitu $16,97 \%$ dan tidak berbeda dengan P2 dan P3. Jahe emprit mengandung senyawa volatil yaitu minyak atsiri dan senyawa nonvolatil yaitu oleoresin. Bagian oleoresin yaitu gingerol adalah senyawa yang tidak dapat larut dalam pelarut air melainkan larut dalam pelarut organik (Widayat et al., 2017). Daun salam mengandung senyawa flavonoid diantaranya yaitu kuersetin dan fluoretin dapat larut dalam pelarut air (Prahastuti et al., 2011).

Pernyataan ini sesuai dengan hasil penelitian Savitri et al., (2019) bahwa semakin meningkat 
penambahan bubuk jahe merah pada teh, maka kadar ekstrak dalam air akan semakin menurun. Pada penelitian ini kadar ekstrak dalam air yang diperoleh dengan perlakuan penambahan bubuk jahe emprit $0 \%$ sampai $20 \%$ tidak sesuai dengan standar SNI 4324:2014 tentang teh hijau celup yaitu memiliki standar kadar ekstrak dalam air minimal $32 \%$.

\section{Total Fenol}

Hasil sidik ragam menunjukkan bahwa perlakuan penambahan bubuk jahe emprit berpengaruh nyata $(\mathrm{P}<0,05)$ terhadap total fenol teh celup herbal daun salam. Hasil penelitian menunjukkan nilai rata-rata total fenol teh celup herbal daun salam berkisar 2,98 mgGAE/g - 3,35 mgGAE/g (Tabel 2). Total fenol tertinggi diperoleh dari perlakuan $\mathrm{P} 4$ sebesar 3,35 $\mathrm{mgGAE} / \mathrm{g}$. Total fenol terendah diperoleh dari perlakuan $\mathrm{P} 0$ sebesar 2,98 $\mathrm{mgGAE} / \mathrm{g}$ dan tidak berbeda dengan P1. Hal ini disebabkan karena bubuk jahe emprit pada penelitian ini memiliki total fenol sebesar 2,00 mgGAE/g. Hasil penelitian ini juga sesuai dengan penelitian yang dilakukan oleh Pratiwi (2017) mengenai penambahan bubuk jahe emprit terhadap minuman penyegar kopi kahwa yaitu memiliki kenaikan total fenol pada setiap penambahan bubuk jahe emprit yang semakin tinggi.

\section{Total Flavonoid}

Hasil sidik ragam menunjukkan bahwa perlakuan penambahan bubuk jahe emprit berpengaruh nyata $(\mathrm{P}<0,05)$ terhadap total flavonoid teh celup herbal daun salam. Hasil penelitian menunjukkan nilai rata-rata total flavonoid teh celup herbal daun salam berkisar 0,45 $\mathrm{mgQE} / \mathrm{g}-0,62 \mathrm{mgQE} / \mathrm{g}$ (Tabel 2). Total flavonoid tertinggi diperoleh dari perlakuan $\mathrm{P} 4$ sebesar 0,62 mgQE/g dan tidak berbeda nyata dengan $\mathrm{P} 2$ dan P3. Total flavonoid terendah diperoleh dari perlakuan P0. Semakin meningkat penambahan bubuk jahe emprit maka semakin tinggi total flavonoid teh celup herbal daun salam. Hal ini disebabkan karena pada penelitian ini senyawa flavonoid pada bubuk jahe emprit sebesar 0,20 mgQE/g. Jahe emprit mengandung senyawa flavonoid berupa kuersetin, rutin, katekin, dan epikatekin yang bersifat semi polar (Ghasemzadeh et al., 2010). Menurut Adawiah et al., (2016), senyawa flavonoid berpotensi sebagai antioksidan karena senyawa flavonoid mampu berperan aktif dalam menangkap radikal bebas. Senyawa flavonoid dapat berperan sebagai agen pendonor atom hidrogen dan memiliki aktivitas biologis yang dapat membantu memelihara sistem metabolisme tubuh.

\section{Aktivitas Antioksidan dan $\mathbf{I C}_{\mathbf{5 0}}$}

Hasil sidik ragam menunjukkan bahwa perlakuan penambahan bubuk jahe emprit berpengaruh nyata $(\mathrm{P}<0,05)$ terhadap aktivitas antioksidan teh celup herbal daun salam. Hasil penelitian menunjukkan nilai rata-rata total flavonoid teh celup herbal daun salam memiliki rentang 32,75\%-73,90\% (Tabel 3). Aktivitas antioksidan tertinggi diperoleh dari perlakuan P4 sebesar 73,90\%. Aktivitas antioksidan terendah diperoleh dari perlakuan P0 sebesar 32,75\%.

Aktivitas antioksidan semakin meningkat seiring dengan meningkatnya jumlah penambahan bubuk jahe emprit. Pada penelitian ini bubuk jahe emprit mengandung aktivitas antioksidan sebesar $60,21 \%$. Hal ini juga didukung oleh penelitian 
Raharjo (2016) yang menyatakan bahwa senyawa antioksidan minuman beluntas jahe meningkat seiring dengan meningkatnya penambahan bubuk ekstrak jahe emprit. Aktivitas antioksidan dipengaruhi oleh senyawa fenol dan senyawa flavonoid sehingga semakin tinggi kandungan fenol dan flavonoid yang terkandung pada teh celup herbal daun salam maka semakin tinggi pula senyawa antioksidan. Jahe emprit memiliki senyawa fenol berupa oleoresin yang berfungsi juga sebagai senyawa antioksidan. Oleoresin berfungsi untuk mencegah adanya proses oksidasi dengan cara menangkap radikal bebas sehingga adanya oleoresin mampu berperan sebagai antioksidan. Menurut Hernani dan Winarti (2014) menjelaskan bahwa senyawa antioksidan alami dalam jahe cukup tinggi sehingga mampu menghambat radikal bebas.

Berdasarkan hasil analisis aktivitas antioksidan, teh celup herbal daun salam dengan penambahan bubuk jahe emprit memiliki nilai $\mathrm{IC}_{50}$ berkisar antara 640,99 ppm - 1488,05 ppm. Semakin besar penambahan bubuk jahe emprit maka semakin rendah nilai $\mathrm{IC}_{50}$ sehingga kemampuan untuk mencegah reaksi oksidasi menjadi lebih tinggi. Hal ini disebabkan karena jahe emprit memiliki senyawa fenol berupa oleoresin yang berfungsi sebagai senyawa antioksidan. Teh celup herbal daun salam dengan penambahan bubuk jahe emprit memiliki potensi antioksidan sangat lemah dimana nilai $\mathrm{IC}_{50}$ menunjukkan lebih dari 200 ppm. Secara spesifik, suatu senyawa dikatakan sebagai antioksidan sangat kuat jika nilai $\mathrm{IC}_{50}$ kurang dari 50 ppm, antioksidan kuat untuk $\mathrm{IC}_{50}$ antara 50-100 ppm, antioksidan sedang jika nilai $\mathrm{IC}_{50}$ bernilai 101-150 ppm, antioksidan lemah jika $\mathrm{IC}_{50}$ bernilai 151-200 ppm dan antioksidan sangat lemah jika $\mathrm{IC}_{50}$ bernilai lebih dari 200 ppm (Rahmawati, 2004).

\section{Sifat Sensoris}

Sifat sensoris teh celup herbal daun salam dilakukan dengan uji skoring terhadap aroma dan rasa, serta uji hedonik terhadap warna, aroma, rasa, dan penerimaan keseluruhan. Nilai rata-rata uji hedonik terhadap warna, aroma, rasa, dan penerimaan keseluruhan dapat dilihat pada Tabel 4, sedangkan nilai rata-rata uji skoring terhadap aroma dan rasa dapat dilihat pada Tabel 5.

\section{Warna}

Hasil sidik ragam menunjukkan bahwa perlakuan penambahan bubuk jahe emprit berpengaruh nyata $(\mathrm{P}<0,05)$ terhadap penerimaan warna (uji hedonik) seduhan teh celup herbal daun salam. Berdasarkan Tabel 4. menunjukkan nilai kesukaan tertinggi terhadap warna teh celup herbal daun salam terdapat pada perlakuan P0 (bubuk jahe emprit $0 \%$ ) sebesar 4,08 yaitu suka dan tidak berbeda dengan P1. Sedangkan nilai kesukaan terendah terhadap warna teh celup herbal daun salam terdapat pada perlakuan P2 (bubuk jahe emprit 5\%) dan P4 (bubuk jahe emprit 20\%) sebesar 3,52 yaitu biasa dan tidak berbeda dengan P3. Hal ini disebabkan karena panelis menilai warna pada kedua perlakuan tersebut memiliki warna yang sama.

Daun salam memiliki warna kuning sebagai pewarna alami (Azhar et al., 2019). Apabila ditambahkan jahe emprit, teh celup herbal daun salam akan berwarna menjadi kuning cerah. Hal ini disebabkan karena jahe emprit mengandung 
senyawa oleoresin yang menghasilkan warna kekuningan sehingga semakin banyak penambahan bubuk jahe emprit ke dalam produk teh celup herbal maka seduhan teh celup herbal daun salam akan semakin berwarna kuning. Hal ini juga didukung oleh penelitian Pebiningrum dan Joni (2018) bahwa kandungan oleoresin pada jahe emprit mempengaruhi warna kombucha jahe.

Tabel 4. Nilai rata-rata uji hedonik terhadap warna, aroma, rasa, dan penerimaan keseluruhan teh celup herbal daun salam

\begin{tabular}{ccccc}
\hline $\begin{array}{c}\text { Perlakuan } \\
\text { penambahan } \\
\text { bubuk jahe } \\
\text { emprit (\%) }\end{array}$ & Warna & Aroma & Rasa & $\begin{array}{c}\text { Penerimaan } \\
\text { Keseluruhan }\end{array}$ \\
\hline P0 (0\%) & $4,08 \pm 0,98 \mathrm{a}$ & $3,12 \pm 0,88 \mathrm{c}$ & $3,12 \pm 0,93 \mathrm{~b}$ & $3,20 \pm 0,87 \mathrm{c}$ \\
P1 (5\%) & $3,68 \pm 0,69 \mathrm{ab}$ & $3,28 \pm 0,68 \mathrm{c}$ & $3,24 \pm 0,60 \mathrm{~b}$ & $3,28 \pm 0,68 \mathrm{c}$ \\
P2 (10\%) & $3,52 \pm 0,82 \mathrm{~b}$ & $3,52 \pm 0,59 \mathrm{bc}$ & $3,32 \pm 0,56 \mathrm{~b}$ & $3,60 \pm 0,58 \mathrm{bc}$ \\
P3 (15\%) & $3,48 \pm 0,58 \mathrm{~b}$ & $3,84 \pm 0,47 \mathrm{ab}$ & $3,48 \pm 0,47 \mathrm{~b}$ & $3,92 \pm 0,64 \mathrm{ab}$ \\
P4 (20\%) & $3,52 \pm 0,58 \mathrm{~b}$ & $4,00 \pm 0,76 \mathrm{a}$ & $3,92 \pm 0,40 \mathrm{a}$ & $4,04 \pm 0,61 \mathrm{a}$ \\
\hline
\end{tabular}

Keterangan: Nilai rata-rata yang diikuti oleh huruf yang berbeda pada kolom yang sama menunjukkan perlakuan yang berbeda nyata $(\mathrm{P}<0,05)$

Kriteria hedonik = 5 (Sangat suka); 4 (Suka); 3 (Biasa); 2 (Tidak suka); 1 (Sangat tidak suka).

Tabel 5. Nilai rata-rata uji skoring terhadap aroma dan rasa teh celup herbal daun salam

\begin{tabular}{ccc}
\hline $\begin{array}{c}\text { Perlakuan penambahan } \\
\text { bubuk jahe emprit (\%) }\end{array}$ & Aroma (Skoring) & Rasa (Skoring) \\
\hline P0 (0\%) & $2,00 \pm 0,87 \mathrm{c}$ & $1,64 \pm 0,57 \mathrm{~d}$ \\
P1 (5\%) & $2,76 \pm 0,78 \mathrm{~b}$ & $2,64 \pm 0,57 \mathrm{c}$ \\
P2 $(10 \%)$ & $3,04 \pm 0,84 \mathrm{~b}$ & $2,76 \pm 0,60 \mathrm{c}$ \\
P3 (15\%) & $3,72 \pm 0,46 \mathrm{a}$ & $3,52 \pm 0,51 \mathrm{~b}$ \\
P4 (20\%) & $3,96 \pm 0,73 \mathrm{a}$ & $4,00 \pm 0,58 \mathrm{a}$ \\
\hline
\end{tabular}

Keterangan: Nilai rata-rata yang diikuti oleh huruf yang berbeda pada kolom yang sama menunjukkan perlakuan berbeda nyata $(\mathrm{P}<0,05)$

Kriteria untuk aroma $=5$ (Sangat khas jahe emprit); 4 (Khas jahe emprit); 3 (Agak khas jahe emprit); 2 (Tidak khas jahe emprit); 1 (Sangat tidak khas jahe emprit).

Kriteria untuk rasa = 5 (Sangat pedas); 4 (Pedas); 3 (Agak pedas); 2 (Tidak pedas); 1 (Sangat tidak pedas)

\section{Aroma}

Hasil sidik ragam menunjukkan bahwa perlakuan penambahan bubuk jahe emprit berpengaruh nyata $(\mathrm{P}<0,05)$ terhadap penerimaan aroma (uji hedonik) seduhan teh celup herbal daun salam. Berdasarkan Tabel 4. menunjukkan nilai kesukaan tertinggi terhadap aroma teh celup herbal daun salam terdapat pada perlakuan P4 (bubuk jahe emprit 20\%) sebesar 4,00 yaitu suka dan tidak berbeda dengan P3. Sedangkan nilai kesukaan terendah terhadap aroma teh celup herbal daun salam terdapat pada perlakuan P0 (bubuk jahe emprit $0 \%$ ) sebesar 3,12 yaitu biasa dan tidak berbeda dengan P1 dan P2. Hal ini disebabkan karena aroma jahe emprit semakin kuat seiiring dengan adanya penambahan bubuk jahe 
emprit.

Hasil sidik ragam menunjukkan bahwa penambahan bubuk jahe emprit berpengaruh nyata $(\mathrm{P}<0,05)$ terhadap penerimaan aroma (uji skoring) seduhan teh celup herbal daun salam. Berdasarkan Tabel 5. menunjukkan rasa (uji skoring) teh celup herbal daun salam, tertinggi terdapat pada perlakuan P4 (bubuk jahe emprit 20\%) sebesar 3,96 yaitu khas jahe emprit dan tidak berbeda dengan P3. Sedangkan rasa (uji skoring) teh celup herbal daun salam terendah terdapat pada perlakuan P0 (bubuk jahe emprit 0\%) sebesar 2,00 yaitu tidak khas jahe emprit. Hal ini disebabkan karena jahe emprit mengandung minyak atsiri yaitu zingiberene dan zingiberol sehingga dapat memberikan aroma khas jahe emprit (Koswara, 1995). Menurut penelitian yang dilakukan oleh Kawiji et al., (2011) yang menyatakan bahwa semakin tinggi konsentrasi jahe emprit maka aroma yang ditimbulkan semakin kuat.

\section{Rasa}

Hasil sidik ragam menunjukkan bahwa penambahan bubuk jahe emprit berpengaruh nyata $(\mathrm{P}<0,05)$ terhadap penerimaan rasa (uji hedonik) seduhan teh celup herbal daun salam. Berdasarkan Tabel 4. menunjukkan nilai kesukaan tertinggi terhadap rasa teh celup herbal daun salam terdapat pada perlakuan P4 (bubuk jahe emprit 20\%) sebesar 3,92 yaitu suka. Sedangkan nilai kesukaan terendah terhadap rasa teh celup herbal daun salam terdapat pada perlakuan P0 (bubuk jahe emprit $0 \%$ ) sebesar 3,12 yaitu biasa dan tidak berbeda dengan P1, P2, dan P3. Hal ini disebabkan karena rasa sepat pada daun salam semakin tertutupi oleh rasa pedas jahe emprit seiring dengan adanya penambahan bubuk jahe emprit sehingga tidak ada rasa sepat lagi.

Hasil sidik ragam menunjukkan bahwa penambahan bubuk jahe emprit berpengaruh nyata $(\mathrm{P}<0,05)$ terhadap rasa (uji skoring) seduhan teh celup herbal daun salam. Berdasarkan Tabel 5. menunjukkan rasa (uji skoring) teh celup herbal daun salam tertinggi terdapat pada perlakuan P4 (bubuk jahe emprit 20\%) sebesar 4,00 yaitu khas jahe emprit. Sedangkan rasa (uji skoring) teh celup herbal daun salam terendah terdapat pada perlakuan P0 (bubuk jahe emprit 0\%) sebesar 1,64 yaitu tidak kahs jahe emprit. Hal ini disebabkan karena jahe emprit mengandung senyawa oleoresin yang berperan dalam memberikan cita rasa pedas (Fathona, 2011).

\section{Penerimaan Keseluruhan}

Hasil sidik ragam menunjukkan penambahan bubuk jahe berpengaruh nyata $(\mathrm{P}<0,05)$ terhadap penerimaan keseluruhan (uji hedonik) seduhan teh celup herbal daun salam. Berdasarkan Tabel 4 menunjukkan nilai kesukaan tertinggi terhadap penerimaan keseluruhan teh celup herbal daun salam terdapat pada perlakuan P4 (bubuk jahe emprit 20\%) sebesar 4,04 yaitu suka. Sedangkan nilai kesukaan terendah terhadap penerimaan keseluruhan teh celup herbal daun salam terdapat pada perlakuan P0 (bubuk jahe emprit 0\%) sebesar 3,20 yaitu biasa dan tidak berbeda dengan P1 dan P2. Penerimaan keseluruhan teh celup herbal daun salam dipengaruhi oleh berbagai faktor seperti warna, aroma, dan rasa.

\section{KESIMPULAN}

Penambahan bubuk jahe emprit pada teh celup 
herbal daun salam berpengaruh nyata terhadap kadar air, kadar ekstrak dalam air, total fenol, total flavonoid, aktivitas antioksidan, $\mathrm{IC}_{50}$, warna (uji hedonik), aroma (uji hedonik dan uji skoring), rasa (uji hedonik dan uji skoring), dan penerimaan keseluruhan (uji hedonik). Penambahan bubuk jahe emprit 20\% menghasilkan teh celup herbal daun salam dengan karakteristik terbaik dengan kadar air $8,93 \%$, kadar ekstrak dalam air $16,97 \%$, total fenol 3,35 mgGAE/g, total flavonoid $0,62 \mathrm{mgQE} / \mathrm{g}$, aktivitas antioksidan 73,90\%, IC $\mathrm{IC}_{50} 640,99 \mathrm{ppm}$, warna teh daun salam biasa, aroma khas jahe emprit dan suka, rasa khas jahe emprit dan suka, dan penerimaan keseluruhan suka

\section{UCAPAN TERIMAKASIH}

Terimakasih penulis ucapkan kepada Program Studi Teknologi Pangan, dosen pembimbing dan rekan-rekan yang telat membantu proses penelitian yang saya lakukan.

\section{DAFTAR PUSTAKA}

Anonimus. 2014. Standar Nasional Indonesia (SNI) 4324:2014. Syarat Mutu Teh Hijau Celup. Dewan Standar Nasional Indonesia (DSN). Jakarta

Adawiah, A., D. Sukandar, dan A. Muawanah. 2016. Aktivitas antioksidan dan kandungan komponen bioaktif sari buah namnam. Jurnal Kimia VALENSI: Jurnal Penelitian dan Pengembangan Ilmu Kimia. 1(2): 130-136

Ambari, Y. 2018. Uji aktivitas antidiare ekstrak etanol daun salam (Eugenia polyantha Wight) pada mencit putih (Mus musculus) jantan galur BALBC. Journal of Pharmaceutical Care Anwar Medika. 1(1): 25

AOAC, Association. of Official Analytical Chemists. 1990. Official methods of analysis. Method 985.29. 15th (eds. Washington D.C.

Aprilia, M., N.W. Wisaniyasa, dan I.K. Suter. 2020. Pengaruh suhu dan lama pelayuan terhadap karakteristik teh herbal daun kenikir (Cosmos caudatus Kunth.). Jurnal Itepa. 9(2):136-150
Azhar, H.Y., D. S. Zustika dan H. Suhendy. 2019. Identifikasi dan uji stabilitas zat warna kuning dari ekstrak etil asetat daun salam (Syzygium polyanthum) menggunakan spektrofotometri UVVis. Pharmacoscript. STIKes Bakti Tunas Husada.Tasikmalaya. 1(2):21-28

Dewi, J. K., L.M.E. Purwijantiningsih, dan F.S. Pranata. 2016. Kualitas teh celup dengan kombinasi teh oolong dan daun stevia (Stevia rebaudiana Bertonii). Jurnal Teknobiologi. Universitas Atmajaya Yogyakarta. Hlm 2

Dewi, A. C. 2018. Pengaruh Perbedaan Suhu Pengeringan Terhadap Karakteristik Teh Daun Salam (Syzygium polyanthum (Wight.) Walp). Skripsi. Fakultas Teknologi Pertanian. Universitas Andalas. Padang.

Djohari, M. dan R. Paramtiha. 2015. Efektivitas rebusan daun salam (Syzygium polyanthum) terhadap penurunan kadar asam urat dalam darah mencit putih jantan. Jurnal Farmasi Sekolah Tinggi Ilmu Farmasi. 12(2): 176-184

Eze, J.1. dan K.E. Agbo. 2011. Comparative studies of sun and solar drying of peeled and unpeeled ginger. American Journal of Scientific and Industrial Research. 2(2):136-143.

Fathona, D. 2011. Kandungan Gingerol dan Shogaol, Intensitas Kepedasan dan Penerimaan Panelis Terhadap Oleoresin Jahe Gajah (Zingiber officinale var. Roscoe), Jahe Emprit (Zingiber officinale var. Amarum), dan Jahe Merah (Zingiber officinale var. Rubrum). Skripsi. Tidak dipublikasi. Fakultas Teknologi Pertanian. Institut Pertanian Bogor. Bogor.

Ghasemzadeh, A., H.Z. Jafar and A. Rahmat. 2010. Synthesis of Phenolic and Flavonoids in Ginger (Zingiber officinale var. Roscoe) and Their Effect on Photosynthesis Rate. Molecular Science. 11:4539-4555.

Herawati, H. dan N. Agus. 2007. Peningkatan nilai tambah produk teh hijau rakyat di kecamatan cikalong wetan-kabupaten bandung. Jurnal Pengkajian dan Pengembangan. Teknologi Pertanian. 10(3):241-249.

Hernani dan C. Winarti. 2014. Kandungan bahan aktif jahe dan pemanfaatannya dalam bidang kesehatan. Balai Besar Penelitian dan Pengembangan Pascapanen Pertanian, Bogor.

Imanila, R., Mukson., H. Setyawan. 2018. Analisis preferensi konsumen rumah tangga terhadap teh celup di kota Semarang. Jurnal Optimum. 8(1).

Ishtiaque, S., S. Naz, N. Soomro, K. Khan, and S. Siddiqui. 2015. Antioxidant Activity and Total Phenolics Content of Extracts from Murraya koenigii (Curry Leaves), Laurus nobilis (Bay Leaves), and Camellia sinensis (Tea). Quaid-EAwam University Research Journal of 
Engineering, Science and Technology. 14(2): 2025.

Islamiyati, R., I. N. Saputri. 2018. Uji perbedaan aktivitas antioksidan dengan variasi konsentrasi pelarut etanol $70 \%$ dan $96 \%$ pada ekstrak etanol daun salam menggunakan metode peredaman radikal bebas DPPH. Cendekia Journal of Pharmacy. 2(2): 141

Kawiji, R., Utami dan E.N. Himawan. 2011. Pemanfaatan jahe (Zingiber officinale rosc.) dalam meningkatkan umur simpan dan aktivitas antioksidan pisang salebasah. Jurnal Pangan Jurusan Teknologi Hasil Pertanian. 4(2): 1-10

Kharismawati, M., P.I. Utami., dan R. Wahyuningrum. 2009. Penetapan kadar tanin dalam infusa daun salam (Syzygium polyanthum (Wight.) Walp) secara spektrofotometri sinar tampak. Journal of Pharmacy. 6(1): 22-27

Koswara, W. 1995. Jahe dan Hasil Olahannya. Pustaka Sinar Harapan, Jakarta.

Kusuma, I.G.N.S., I.N.K. Putra, dan L.P.T. Darmayanti. 2019. Pengaruh suhu pengeringan terhadap aktivitas antioksidan teh herbal kulit kakao (Theobroma cacao L.). Jurnal Itepa. 8(1):85-93

Mutiara, D.R., D.W.K. Arti, dan Z. Aprillia. 2018. Efektivitas Flavonoid Ekstrak Daun Salam (Eugenia polyantha W) dalam Menghambat Pertumbuhan Bakteri Streptococcus mutans. Skripsi. Tidak dipublikasi. Fakultas Kedokteran Gigi. Universitas Muhammadiyah Semarang.

Nathaniel, A.N., I.N.K. Putra, dan A.A.I.S. Wiadnyani. 2020. Pengaruh suhu dan waktu pengeringan terhadap aktivitas antioksidan dan sifat sensoris teh herbal celup daun rambusa. Jurnal Itepa. 9(3):308320

Pebiningrum, A dan J. Kusnadi. 2018. Pengaruh varietas jahe (Zingiber officinale) dan penambahan madu terhadap aktivitas antioksidan minuman fermentasi kombucha jahe. Journal of Food and Life Sciences. Universitas Brawijaya. 1(2): 33-42

Prahastuti, S., Tjahjani, S. dan Hartini, E., 2011. The effect of bay leaf infusion ( Syzygium Polyanthum (Wight) Walp) to decrease blood total cholesterol level in dyslipidemia model wistar rats. Jurnal Medika Planta, P. 1(4).

Pratiwi, D. 2017. Pengaruh Penambahan Bubuk Jahe Emprit (Zingiber officinale var. Amarum) Terhadap Karakteristik Kimia dan Sensori Minuman Penyegar Kopi Kahwa. Skripsi. Tidak dipublikasi. Fakultas Teknologi Pertanian.
Universitas Andalas. Padang.

Raharjo, A.L. 2016. Pengaruh Penambahan Bubuk Ekstrak Jahe Emprit (Zingiber officinale var. Amarum) Terhadap Aktivitas Antioksidan Minuman Beluntas (Pluchea indica Less) Jahe. Skripsi. Tidak dipublikasi. Fakultas Teknologi Pertanian. Universitas Katolik Widya Mandala Surabaya. Surabaya.

Rahmawati, D. 2004. Mempelajari Aktivitas Antioksidan dan Mkroba Ekstrak Antarasa (Litsea cubeba) dan Aplikasinya sebagai Pengawet Alami pada Bahan Pangan. Skripsi. Tidak dipublikasi. Fakultas Teknologi Pertanian Institut Pertanian Bogor. Bogor.

Ravikumar, C. 2014. Review on Herbal Teas. Journal of Pharmaceutical Sciences and Research. 6(5): 236238.

Savitri, K.A.M., I.W.R. Widarta dan A.A.G.N.A. Jambe. 2019. Pengaruh perbandingan teh hitam (Camellia sinensis) dan jahe merah (Zingiber officinale var. Rubrum) terhadap karakteristik teh celup. Jurnal Itepa. 8(4):419-429

Suharmiati. 2003. Pengujian Bioaktivitas Antidiabetes Melitus Tumbuhan Obat. Cermin Dunia Kedokteran. 140: 8-9

Sutrisna, E., Y. Nuswantoro, dan R.F. Said. 2018. Hypolipidemic of ethanolic extract of salam bark (Syzygium polyanthum (Wight) Walp.) from Indonesia Preclinical study). Drug Inventiio Today. $10(1)$

Tjay, T.H dan K. Rahardja. 2007. Obat-Obat Penting Khasiat, Penggunaan dan Efek-Efek Sampingnya. Edisi Keenam. 262: 269-271, PT. Elex Media Komputindo, Jakarta.

Widayat, B. Cahyono, H. Satriadi dan S. Munfarida. 2017. Antioxidant activity and total phenolic content in red ginger (Zingiber officinale) based drinks. Series : Earth and Environmental Science 102: 012-025.

Wiradona, I., E. Mardiati dan Sariyem. 2015. Pengaruh berkumur ekstrak daun salam (Eugenia polyantha Wight) terhadap pembentukan plak gigi. Jurnal Riset Kesehatan. 4(5): 768-772.

Wisakarani, N.P.A.; P. Timur Ina dan I.G.A Ekawati. 2016. Pengaruh penambahan bubuk jahe emprit (Zingiber officinale var. Amarum) terhadap karakteristik teh daun kelor (Moringa oleifera). Jurnal Itepa unud. Hlm 8.

Yuliani, S. dan S. Suyanti. 2012. Panduan Lengkap Minyak Atsiri. Penebar Swadaya. Bogor. 